\title{
The First Step of Smart Learning: School Librarians' Stages of Concern about Digital Textbooks in South Korea
}

\author{
Ji Hei Kang \\ Dongduk Women's University \\ 60, Hwarang-ro 13-gil, Seongbuk-gu, Seoul, Korea \\ Republic of Korea \\ jhkang@dongduk.ac.kr
}

\begin{abstract}
Despite the growing importance of technology integration leadership and the emergence of professional guidelines and organizations, there have been only a few studies addressing how to actually improve their leadership. Therefore, this study suggests customized interventions for each group of school librarians that analyze the stages of concern regarding their leadership development. The SoC profile of Korean school librarians presents a typical non-user profile. Information-exchange strategies, professional development, and encouragement from administrators can arouse school librarians' interest.

Information-exchange strategies, professional development, and encouragement from administrators can arouse school librarians' interest.
\end{abstract}

Keywords: smart learning, digital textbook, Stages of Concern

\section{Introduction}

As smart devices have been increasingly adopted, the Korean government has been working on a new education project called "Smart Learning" since 2011 (Ministry of Education Science and Technology, 2011). This new paradigm of education is designed for digital native students in order to not only provide updated and interactive digital learning content, but also to allow them to imbue their learning experiences with customized learning material. With Smart Learning, schools will embrace more information technologies and digital textbooks that include various multimedia contents, which will replace traditional textbooks. 
In accordance with this change, the leadership role of school librarians in technology integration is emerging. Various standards and previous studies compel school librarians to play pivotal roles in integrating educational technologies. In fact, school librarians are already involved in advocating for technology in schools, disseminating information about those technologies, and educating the community about uses for new technologies (Everhart, Mardis, \& Johnston, 2012). However, few school librarians are found to have achieved full or substantial leadership, advocacy, and community partnerships.

Although this new paradigm requires revamping the outdated system of education including current educators, the Korean government does not handle human resource issues-such as identifying employee concerns and fostering professional development. The first step of the proposed study, therefore, was to identify South Korean school librarians' Stages of Concern in terms of digital textbooks, which are an integral part of Smart Learning. By doing so, the researcher can suggest specialized interventions for school librarians as part of their leadership development. In addition, the researcher provides practical interventions based on the Concerns Based Adoption Model (CBAM) in order to help school librarians enhance their leadership in embracing Smart Learning including digital textbooks.

\section{Literature Review}

\section{School librarians' leadership roles in technology integration}

The increasing number of studies and guidelines pertaining to school librarians as well as previous studies have focused on identifying a range of definitions and prototypes for school librarians' leadership roles. Studies examine school librarians' various roles and some studies confirm that the leadership qualities of school librarians are complex and multidimensional, rather than fragmentary (Everhart, 2011; Smith, 2013). Especially in our fast-paced technological society, the leadership of technology integration has been receiving particular attention. School librarians are supposed to help students "develop information skills that will enable them to use technology as an important tool for learning, both now and in the future" (American Association of School Librarians, 2009). Library media programs should make available "the expansion and enhancement of new formats and resources" (National Board for Professional Teaching Standards, 2012).

However, more recent studies commonly offer an important starting point for this study demonstrating the growing importance of school librarians' leadership roles and the emergence of technology integration. Everhart, Mardis, \& Johnston (2012), for example, 
conclude that most school librarians have a strong commitment to technology leadership by offering invaluable expertise to their respective schools, including to faculty and students. While there are more studies emphasizing the importance of school librarians' emerging leadership roles in technology integration, in practice, school librarians are not aligned with studies yet. Moreover, the studies have not provided a procedural guide for improving school librarians' leadership abilities or for providing the tools necessary to effectively evaluate their leadership. This lack may provoke controversy about how to increase or demonstrate leadership, or what the best practices truly are. A study is required to demonstrate what the stages of school librarians' leadership are, and to illustrate the interventions to help them develop their roles in technology integration.

\section{Smart learning and digital textbooks in South Korea}

As mentioned above, Korean government embarked SMART learning, which means 'Self-directed, Motivated, Adaptive, Resource free, Technology embedded' (Ministry of Education Science and Technology, 2011). digital textbooks, online class and evaluation, free use of educational content and safe environment based on strengthening teacher's competency for smart teaching and cloud-based education service. For students, this program encourages students' self-directed and individualized learning and collaborated learning.

Regarding to teachers, they can allow students to use various teaching materials. In terms of parents, they can develop trustiness of public education by knowing students' study information. The main method to realize this SMART education, is digital textbooks. Since digital textbooks provide abundant information from the internet, and that information includes not only textbooks, references, workbooks and self-teaching guides, but also rich multimedia content including games, animations, video-audio clips, internet-based virtual laboratories and virtual reality (Kim \& Jung, 2010; Mardis et al., 2010), school librarians should develop more and various digital collections, and make sure that the library collection is up to date (American Association of School Librarians, 2009). In fact, previous research has found that school librarians are in charge of identifying and implementing digital content and purchasing or downloading books (Mardis \& Everhart, 2011; Wolf, Jones, \& Gilbert, 2014). Another feature of digital textbooks is working in a device. Since textbooks are non-exclusive, all students need devices. In order to build the learning environment (American Association of School Librarians, 2009), school librarians take care of creating a policy regarding devices such as a "Bring Your Own Device" (BYOD) or "Bring Your Own Technology" (BYOT) program, 
purchasing and registering devices and maintaining e-readers (Mardis \& Everhart, 2011; Wolf et al., 2014).

Pedagogically, digital textbooks enable differentiation within instruction. Since digital textbooks can differ depending on each student's level, teachers can offer personalized and customized teaching, and this differentiated strategy allows teachers to set student-centered immersive activities and assignments (Kim \& Jung, 2010). Digital textbooks also enable educators to do more collaborative work and promote social interaction with other educators (McKiernan, 2011). Therefore, school librarians need to recognize the new way to promote students' creativity, to collaborate with other educators and support them in use of digital textbooks (Mardis \& Everhart, 2011).

\section{Methodology}

\section{CBAM}

The study employed a survey method applying CBAM as a theory. The CBAM is one acknowledged approach to identify stages of concern in an individual educator. The term "concern" indicates the comprehensive feelings and knowledge about a particular event or innovation. The CBAM "consists of three diagnostic dimensions that provide evidence of the current extent and quality of implementation, which leaders can use to drive decisions and actions"(SEDL, 2015, para.7). The CBAM includes the concepts of stages of concern (SoC), levels of use (LoU), innovation configurations (IC), change facilitator styles, and interventions (Anderson, 1997; Dorksen \& Tharp, 1997). Among the three diagnostic methods, this study focuses on the first tool, $\mathrm{SoC}$, in order to make a diagnosis of school librarians' stages of concern as a preliminary study.

Assuming change is a process, the Stages of Concern (SoC) sets seven stages of concern. If someone has encountered an innovation, this person may express concern ranging over the various stages, but could have a higher interest in a particular stage. Those in the first step, Step 0: unconcerned, are uninterested in the innovation because of their time constraints. From the next stage, educators express their interest, and each stage represents specific interests: Stage 1: informational; Stage 2: personal; Stage 3: management; Stage 4: consequence; Stage 5: collaboration; and Stage 6: refocusing.

\section{Application of CBAM in leadership studies}

The critical method to identify Stages of Concern is to employ SoCQ (Stages of Concern Questionnaire), which is a survey method applying 35 questions (Hall, 1974). Since the 1980s, the CBAM has been applied to evaluate educational innovations. Several researchers have 
applied the SoCQ to enhance educators' leadership roles in implementing new innovations. For example, Hord and Thurber (1982) trained principals how to use the SoCQ to enhance their leadership skills when integrating a new curriculum. According to the authors, principals in Florida identified school teachers' concerns and applied interventions to address them. Most principals reported that the given interventions solicited teachers' concerns, and this study confirms that principals' engagement with the leadership tools helped the teachers address each of the stages of their concerns.

\section{Data collection procedure}

Since the Korean version of the SoCQ was not developed officially, the researcher created the Korean SoCQ with one of creators. For the translation and review processes, the researcher employed a back-translation approach. First, the researcher translated the latest SoCQ, form 075, into Korean referring to the previous Korean studies. Two other bilingual (Korean-English) doctoral students in the College of Education at Florida State University, who have never seen the English SoCQ, translated the Korean items back into English. Then, one of the CBAM founders compared the back-translated English version with the original version and identified the items with discrepancies in meaning.

The researcher employed availability sampling and obtained 259 completed surveys, representing $5.1 \%$ of the 2,000 invitations sent from November to December 2014 . The researcher employed Qualtrics survey tool, which offered a user-friendly interface for setting up the survey and for participants to access from various devices, such as computers and mobile phones.

Since the South Korean version of SoCQ was employed for the first time, data reliability for each variable was checked by Cronbach's alpha, the most frequently used test for internal consistency (Gliem \& Gliem, 2003), ranging between 0 and 1, closer to 1.0 indicating greater internal consistency. In the case of Korean survey, the overall Cronbach's alpha was 0.955 , confirming that the survey questionnaire had a strong internal consistency.

\section{Findings}

The research question identifies the peak stage of concerns for South Korean school librarians, as illustrated in Figure 1. The intensity of each stage was $99 \%$ in Stage 0, 88\% in Stage 1, 83\% in Stage 2, 77\% in Stage 3, 33\% in Stage 4, 55\% in Stage 5, and 57\% in Stage 6. Stage 0, Unconcerned, (99\%). The SoC profile indicates that school librarians were interested in learning about digital textbooks, as well as, were concerned about their personal roles; yet, were not fully aware of digital textbooks or immersed in other innovations (George, Hall, \& Stiegelbauer, 2013). In other words, other innovations or activities attract school librarians' concerns now over digital textbooks. 
Let's analyse the profile according to the CBAM theory. Figure 1 described that school librarians had higher percentiles in Stages 0,1 , and 2. This presents a typical non-user profile, which demonstrates more intensity during the Self stages (Stage 0, Unconcerned; Stage 1, Informational; and Stage 2, Personal)(Hall \& Hord, 1987). For non-users, the intensity at Stage 0, Unconcerned, is not as important as the variations in Stages 1 and 2 (George et al., 2013), meaning that school librarians focused more on learning about digital textbooks and were concerned about their personal roles while they were occupied simultaneously with other innovations.

The last interesting pattern is a slightly tailing-up pattern in Stage 6, Refocusing, which implies that participants might be resistant to digital textbooks. The higher intensity of concerns in Stage 6 than Stage 5 may hint at a potential resistance. This conveys that Korean school librarians did not have an opinion about opportunities that could compete with digital textbooks.

Moreover, Korean school librarians also expressed relatively significant concerns during Management, Stage 3. High concerns at Stage 3, Management, imply that the librarians focused on the processes and tasks of using digital textbooks and were interested in the best use of information and resources related to digital textbooks. They were interested in issues about how to improve efficiency, organize jobs, manage times and schedule the implementation. 


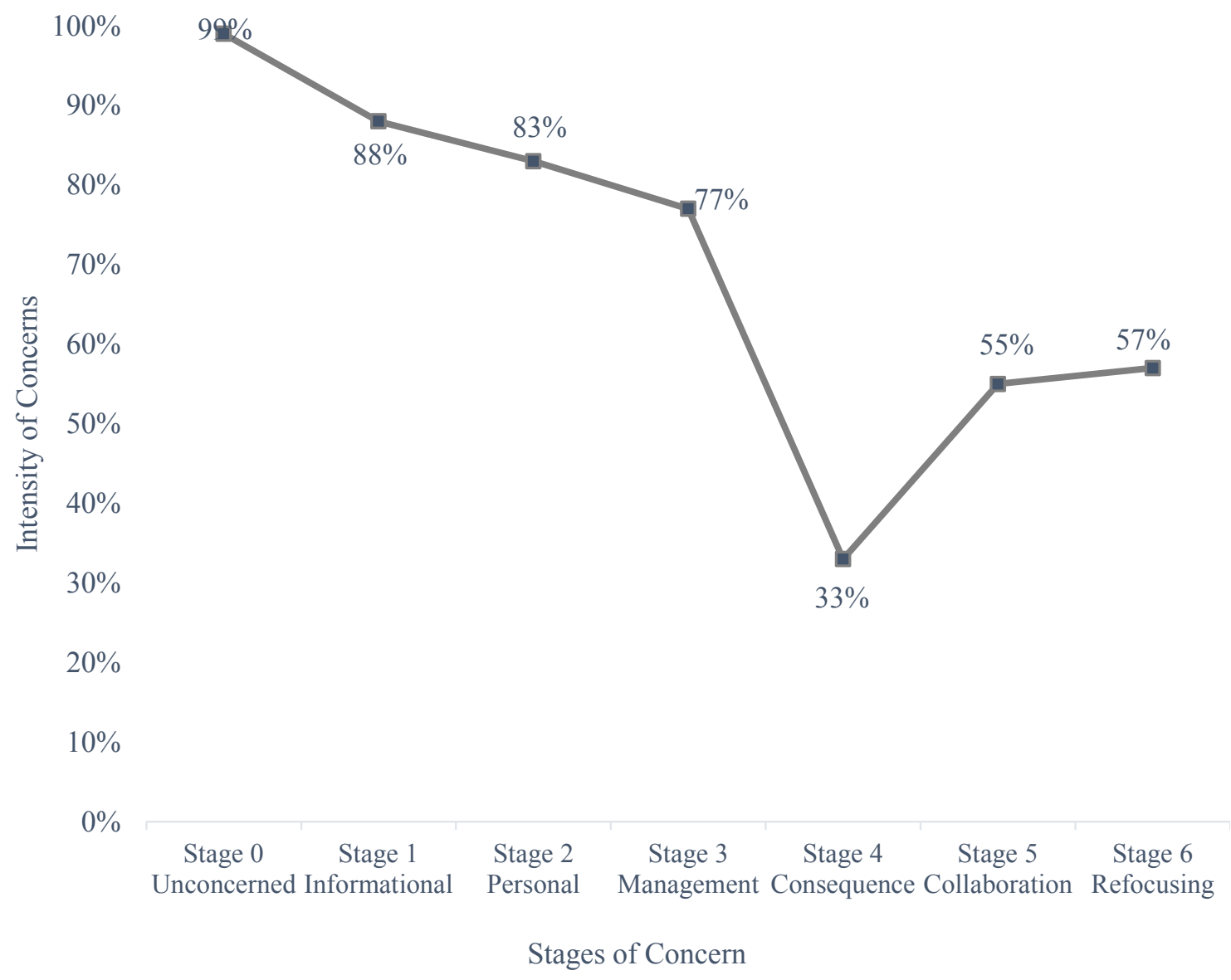

Figure 1: The stages of concern profile with school librarians in South Korea

\section{Discussion and conclusion}

Korean school librarians' SoC profile represented a typical non-user profile, which has more intensity in the Self stages: Stage 0, Unconcerned; Stage 1, Informational; and Stage 2, Personal. School librarians were not fully aware of digital textbooks and were more focused on other responsibilities. However, the high percentages of concern in Stages 1, Informational and 2, Personal, also suggest that they are open to digital textbook implementation and need more information about the innovation (George et al., 2013).

Based on the CBAM theory, the findings underscore a need for various interventions. Since school librarians were found to be apathetic even though digital textbook integration will be put into effect soon, an intervention to inform them of the characteristics and strong points of digital textbooks, as well as restrictions for using them, is urgent (intense Stage 0). Moreover, the study findings argue that it is urgent to introduce various interventions. For example, South Korean school librarians, who had the second-highest concern in Stage 1, Informational, need to receive general information including benefits and costs of digital textbooks. 
To enable school librarians to be leaders in adopting this innovation, the CBAM theory suggests certain interventions. Information-exchange strategies, professional development, and encouragement from administrators can arouse school librarians' interest.

The results from the study stress the importance of professional development for school librarians. Data from the study provides administrators with information regarding interventions that were targeted and customized according to school librarians' characteristics. Moreover, for policy makers, the theory recommends gradual pilot test opportunities in South Korea. Lastly, the study urges library and information science education to have short- and long-term strategies for embracing digital textbooks.

This study investigates the perceptions of school librarians in South Korea about using digital textbooks within a planning period. Because the implementation of digital textbooks is imminent, a top priority for school librarians would be to initiate conversations about digital textbooks and introduce interventions to relieve any concerns.

\section{References}

American Association of School Librarians. (2009). Empowering learners: Guidelines for school library media programs. Chicago: American Association of School Librarians.

Anderson, S. E. (1997). Understanding teacher change: Revisiting the Concerns Based Adoption Model. Curriculum Inquiry, 27(3), 331-367.

Dorksen, D. J., \& Tharp, M. D. (1997). The role of CBAM in teacher education to facilitate systemic change. Technology and Teacher Education Annual 1997, 1064-1067.

Everhart, N. (2011). School Librarian Leadership around the World. School Libraries Worldwide, 17(2), 1-1.

Everhart, N., Mardis, M., \& Johnston, M. P. (2012). National Board Certified school librarians' leadership in technology integration: Results of a national survey. School Library Media Research, 14, 1-19.

George, A. A., Hall, G. E., \& Stiegelbauer, S. M. (2013). Measuring implementation in schools: The stages of concern questionnaire (3rd ed.). Austin, TX: SEDL.

Gliem, J. A., \& Gliem, R. R. (2003). Calculating, interpreting, and reporting Cronbach's alpha reliability coefficient for Likert-type scales. Paper presented at the Midwest Research-to-Practice Conference in Adult, Continuing, and Community Education, The Ohio State University, Columbus, $\mathrm{OH}$.

Hall, G. E. (1974). The Concerns-Based Adoption Model: A Developmental Conceptualization of the Adoption Process Within Educational Institutions. Paper presented at the the Annual Meeting of the American Educational Research Association Chicago, Illinois.

Hall, G. E., \& Hord, S. M. (1987). Change in schools: Facilitating the process. Albany, N.Y: State University of New York Press. 
Hord, S. M., \& Thurber, J. C. (1982). Implications for research: Preparing principals for leadership roles. Paper presented at the the American Educationl Research Association, New York City.

Kim, J. H.-Y., \& Jung, H.-Y. (2010). South Korean digital textbook project. Computers in the Schools, 27(3-4), 247-265. doi:10.1080/07380569.2010.523887

Mardis, M., \& Everhart, N. (2011). Digital textbooks in Florida: Extending the teacher-librarians' reach. Teacher Librarian, 38, 8-11.

McKiernan, G. (2011). Configuring the 'Future Textbook'. Searcher, 19(4), 43-47.

Ministry of Education Science and Technology. (2011). Action Plan announced for full-scale introduction of smart training [Press release]. Retrieved from http://www.moe.go.kr/web/100026/ko/board/view.do?bbsld=294\&boardSeq=34952

SEDL. (2015). Concerns-Based Adoption Model (CBAM). Retrieved from http://www.sedl.org/cbam/

Smith, A. P. (2013). The Leadership potential of school librarians. (Ed.D.), The George Washington University, Ann Arbor. Retrieved from ProQuest Dissertations \& Theses Full Text database. (UMI No. 3557505)

Wolf, M. A., Jones, R., \& Gilbert, D. (2014). Leading in and beyond the library. Retrieved from Washington, DC: http://all4ed.org/reports-factsheets/leading-in-and-beyond-the-library/

\section{Biographical note}

Ji Hei Kang has been working as an assistant professor at Dongduk Women's University in Seoul, South Korea.

The main topic that she focuses on is school librarians' leadership role in implementing technological innovations. For her dissertation project, she conducted research concerning school librarians' Stages of Concern in employing digital textbooks. She plans to follow up her research by applying a qualitative method to identify school librarians' Level of Use of digital textbooks. She is also interested in studying how librarians promote new types of educational technology, such as mobile augmented reality and big data. She can be contacted at jhkang@dongduk.ac.kr. 